\title{
Espaços de lazer e culturas jovens em Brasília: o caso de bares
}

\author{
Gilberto Luiz Lima Barral
}

Curso: Mestrado em Sociologia

Data de defesa: 20 de abril de 2006

Orientador: Prof. Dr. Arthur Trindade Maranhão Costa

\section{Resumo}

A presente pesquisa nasceu da observação de que juventude e lazer têm sido categorias que vêm se construindo, paralelamente, ao longo do século XX, a partir das últimas décadas. Nessa relação entre juventude e lazer, novas formas de ocupação do tempo livre, em muitos casos impregnadas pela indústria cultural e de consumo, vêm promovendo sociabilidades alternativas que impactam sobre as formas de vivência e representação das categorias lazer e juventude. $\mathrm{Na}$ interseção dessas duas categorias, Brasília torna-se emblemática, se acompanharmos o desenvolvimento de seus espaços de lazer e as juventudes que vêm se afirmando nesta cidade. Nesse sentido, esta dissertação apresenta determinados espaços de lazer no Plano Piloto e as culturas jovens que fazem desses lugares espaços de freqüentação, de divertimento e de encontros juvenis.

Para a realização deste trabalho, buscou-se na extensa obra de Joffre Dumazedier o material teórico para discutir o problema do lazer nas sociedades modernas. Para a análise da construção sociocultural da categoria juventude, recuperaram-se autores como Karl Mannheim, David Matza e Pierre Bourdieu, dentre outros envolvidos em pesquisas sobre culturas jovens. Em Georg Simmel e Michel Maffesoli buscaram-se argumentos para discutir o problema da relação grupo-espaço. 
Do ponto de vista metodológico, a teoria das representações sociais de Serge Moscovici propiciou conhecer mais de perto as vivências e representações sobre lazer e grupos jovens do Plano Piloto. Em termos empíricos, a pesquisa recaiu sobre o lazer noturno de grupos jovens universitários brasilienses, particularmente nos bares, os quais surgem como espaços propícios à conversação e interação entre grupos jovens. Isso vem reafirmar, então, a relação entre juventude e lazer como categorias que vêm se construindo e reconstruindo, paralelamente, ao longo da modernidade.

Palavras-chave: juventude, lazer, cultura urbana, grupos de estilo. 